\title{
The Examination and Teaching of Different Geographic Conditions with VR/AR Instruments
}

\author{
Gulyás István \\ ELTE PPK University, Budapest, Hungary \\ Réka Bokor dr. \\ PTE FDI University, Budapest, Hungary
}

\begin{abstract}
Geography, the study of our planet Earth has a history of hundreds or even a thousand years, e.g.: based on Middle Eastern, Egyptian and Chinese descriptions and surviving drafts.

It is apparent from the findings that contemporary experts also recorded their coordinates based on measurements and observations, taking into account the movement of the sun and stars.

Keeping in mind the inaccuracies of these observations we can still see some examples which have been preserved to the present day, e.g.: the disproportionate maps of the eastern coast of the North American continent from the 16th-17th centuries.

In the 21st century the field of geoinformatics or geocomputation (geographic information science in Hungarian terminology) deals with primary and secondary data collection procedures, geographical analyses and thematic map display. The processing of a significant amount of spatial data requires high IT capacity as the display of this data results in $2 D$ and $3 D$ display today. These traditional modes of display are, however, no longer sufficient for the visualisation (e.g.: recording, processing, etc.) of time-varying processes and the more accurate representation of the dynamics of these phenomena.

The instruments of Virtual Reality (VR) and Augmented Reality (AR) give an alternative solution here, not only by providing users with the required visualisation but also with new alternatives in the field of analyses, research, services and regulations for further research, for "almost" immediate use and application of processed data.

Present research looks at the effectiveness of existing digital devices (hereafter HW, SW), their appropriateness for teaching purposes and further areas for their application that can be available on mobile devices, too.
\end{abstract}

Keywords: geography, land policy, EU geographical-digital regulations, virtual reality (VR), augmented reality (AR), GPS, UHD, education technology, artificial intelligence

\section{INTRODUCTION}

Geographic technologies (remote sensing/RS, global positioning system/GPS, geographic information system/GIS) have gone through rapid development in the 21 st century. The applied systems are capable of recording larger amounts of data in higher resolution.

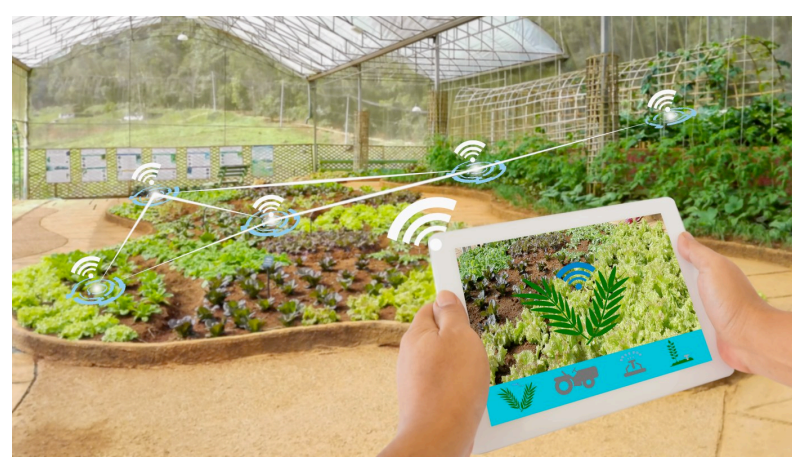

Figure 1 VR applications in agriculture, source: http://intersog.com/blog/augmented-reality/vr-applications-inagriculture

The spectrum of research areas can be significantly increased by complementing $\mathrm{VR} / \mathrm{AR}$ software and hardware tools with simulation and interaction, analysis of time-space data can be accelerated and new alternative uses (e.g.: new services, education, land management, support scheme, etc.) may appear in the not so distant future of modern geography.

It is clear that significant and accurate visual spatial data provide an opportunity for the development of a modern, digital system of rules for geographical conditions (e.g.: land policy) in Hungary, the European Union and other countries, for which the training of related professionals is indispensable. With this in mind, the professional training of geographers will be expanded with such new education technology elements, VR and AR tools, whose methodological and content aspects are still under development besides other issues.

For this reason, it is important to consider all the existing geoinformatic hardware and software tools (nonexhaustive list) that are currently available, which show a direction to the expected and necessary development and modernisation of education.

The results of these surveys could also serve as a basis for clearing the hiatus in land policy control through which new and modern HW/SW tools can provide multidimensional, hitherto unavailable and even real-time data to professionals (e.g.: Figure 1). [1] 


\section{EXAMINATION OF DIFFERENT GEOGRAPHICAL CONDITIONS WITH HW/SW INSTRUMENTS}

The emergence of information technology has made significant progress in exploration, recording and tracking changes of geographical data. The first decisive step was the steady increase in the storage capacity and operational speed of computers.

However, some aerial and space data collection tools and procedures to be introduced below, which can be considered second generation in geoinformatics, play a more decisive role in the field today.

The results of space research can provide a significant background and thus far more research possibilities for the examination of different geographical conditions (Figure 2). VividX2, developed by Earth-I, is the first commercial satellite capable of taking photos in full-colour and Ultra High Definition (UHD) of any location on the Earth, which accurately reflects the level of currently available technology in our time.

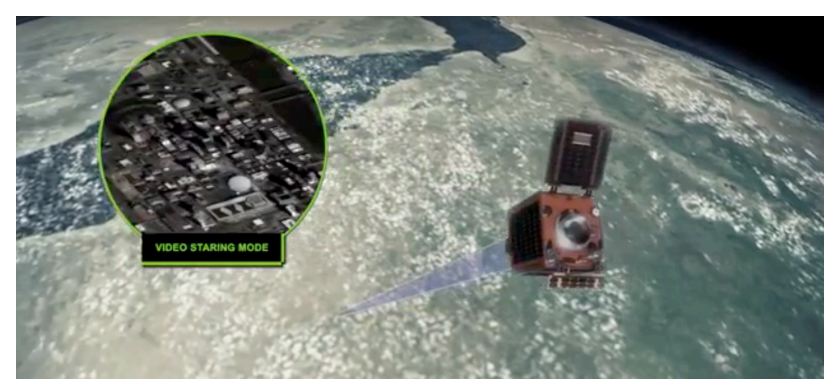

Figure 2 Excerpt from full-colour video taken by Earth-I VividX2 satellite, source: http:/geoinformatics.com/earth-i-releases-its-first-fullcolour-video-of-earth-taken-from-space/

It is important to note that for accurate spatial data and information the work and communication of the available tools needs to build on each other and be coordinated. That is why the signals transmitted by satellites are important for earth devices such as Global Navigation Satellite System (GNSS), with which local measurements can be recorded and performed (Figure 3 ).

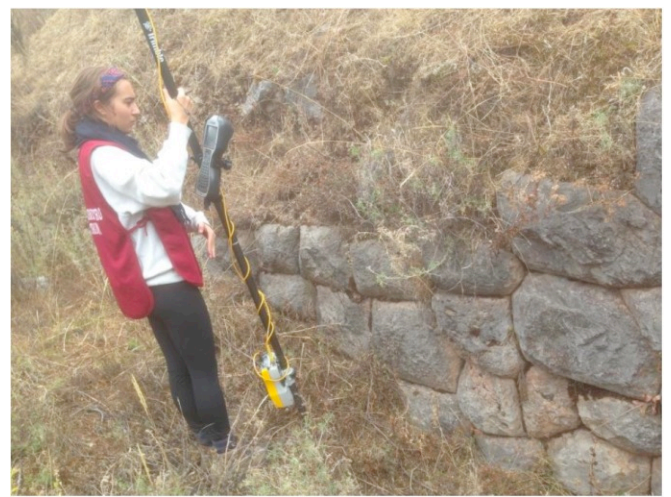

Figure 3 Student Helena Nicholagos performs measurements with GNSS, source: http://geoinformatics.com/original-green-engineerstrimble/
Of course, the aforementioned aerial data collection cannot be ignored, where drones (hereafter UAVs, Unmanned Aerial Vehicles) and related digital image processing systems (e.g.: medical, industrial, agricultural, criminal and safety, etc.) and 3D visualization systems have been becoming increasingly dominant. [2], [9], [10]

The agricultural and geoinformatic use of drones has been increasing year by year [8]. In 2015 in the USA alone, farmers purchased 45,000 UAVs for controlling crops, spraying, etc., which was then an illegitimate activity. In 2017, after modifying the respective regulation, more than $600,000 \mathrm{UAVs}$ served on American lands. (Figure 4) This is expected to grow further with the growth of the range of UAVs and their battery capacity. [6]

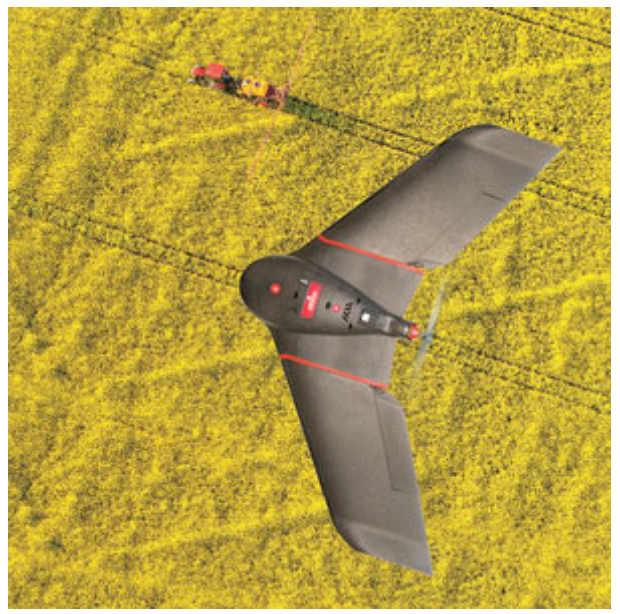

Figure 4 Agricultural drone, source:

https://spectrum.ieee.org/robotics/drones/agriculture-drones-are-finallycleared-for-takeoff

The technological modernization observed in agriculture demonstrates sufficiently that the development of regulation related to different geographical conditions can build on new sets of data and efficiency promoting data gained from those (Figure 5). In the light of the above, it is clear that the international harmonisation of these regulations is essential to support the operation, research and sectoral tasks. [1]

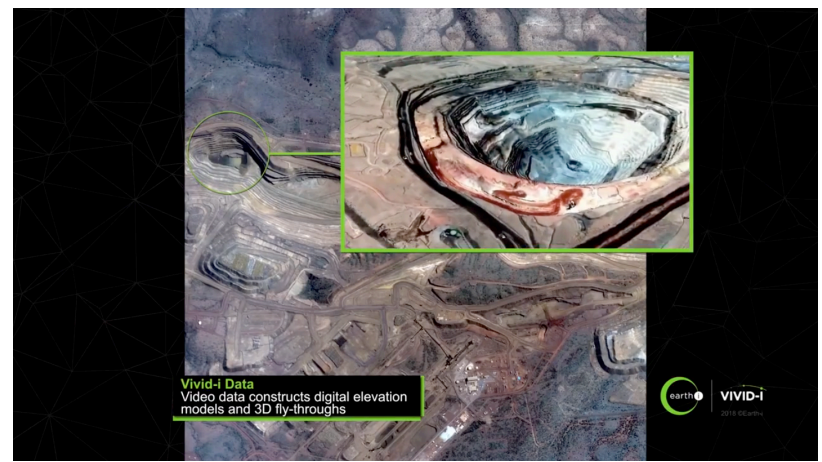

Figure 5 Vivid-I Data: digital height and 3D model based on video data, source: http://geoinformatics.com/earth-i-releases-its-first-full-colourvideo-of-earth-taken-from-space/ 
The dominant tools for examining different geographic conditions are the already mentioned software applications [5], which are now available not only in desktop computer environment but also on our greater performance mobile devices.

Thus the following applications can be distinguished:

- visualisation,

- analysing,

- geo-encoding / navigating,

- research applications.

Related software applications typically cover a single service area from the above list, but multifunctional integrated systems are also becoming widespread.

A prominent example of this is the ArcGIS system (Figure 6 ), which not only provides a broad spectrum of available data, but also a number of related services and necessary data protection for the user.

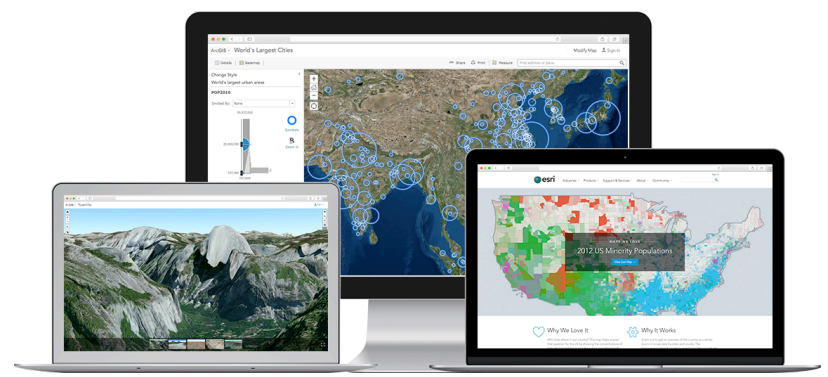

Figure 6 ArcGIS - a complete, cloud based mapping platform source: https://www.arcgis.com/

Due to its complexity, the ArcGIS system is capable of effectively studying and analysing different geographic conditions, which, for example, can provide information (including 3D visualization, water management, hours of sunshine, etc.) for agricultural professionals on how to increase productivity.

Some typical GNSS-based fields of application:

\section{A. Navigation}

- vehicle navigation (Navigation Data Standard NDS)

- air navigation (WAAS, LAAS)

- water surface navigation

- space navigation, etc.

\section{B. Land survey and mapping}

- creating maps that help the construction of buildings and roads: OpenStreetMap, TierraWiki

- archaeological, etc.

\section{Other areas}

- military use

- mobile satellite communication

- emergency and positioning services:

$$
\begin{array}{ll}
\text { ○ games } \\
\text { - marketing }
\end{array}
$$

- air travellers

- weather forecast

- photography

- diving

- Wi-Fi services

- social media, etc.

\section{THIRD GENERATION TOOLS IN GEOINFORMATICS - USE OF VR/AR INSTRUMENTS IN EDUCATION}

The daily work process of many industries has been transformed due to the development of IT systems and the appearance of VR/AR instruments and their availability on a daily basis.

With this in mind, it can be stated that (even agricultural) activities, tasks, functions and services, dealing with different geographical conditions, within the scope of geoinformatics increasingly make use of the benefits of VR/AR technologies (Figure 1).

The reasons for this are for example:

- providing remote access (VR)

- interconnectivity of received data and real image information (AR)

- simultaneous management of multiple devices (VR/AR)

- possibility of immediate intervention in case of a two-way video connection (VR/AR)

- gesture control without IT skills (e.g.: programming)

Based on the above, we can conclude that the third generation stage of development in geoinformatics can be achieved by VR/AR technologies, which require even less technical knowledge from users.

Nevertheless, new types of VR/AR applications require the acquisition of new competencies from general users, the best example of which was the earlier appearance of the mouse in the IT world.

Today, these technologies represent the advancement for this field of study as well as new challenges for those who are presently doing training. [4] It can be concluded that generally accepted methodologies and pedagogical good practices are currently not available but their application has become a more pressing issue for trainings mentioned above. 


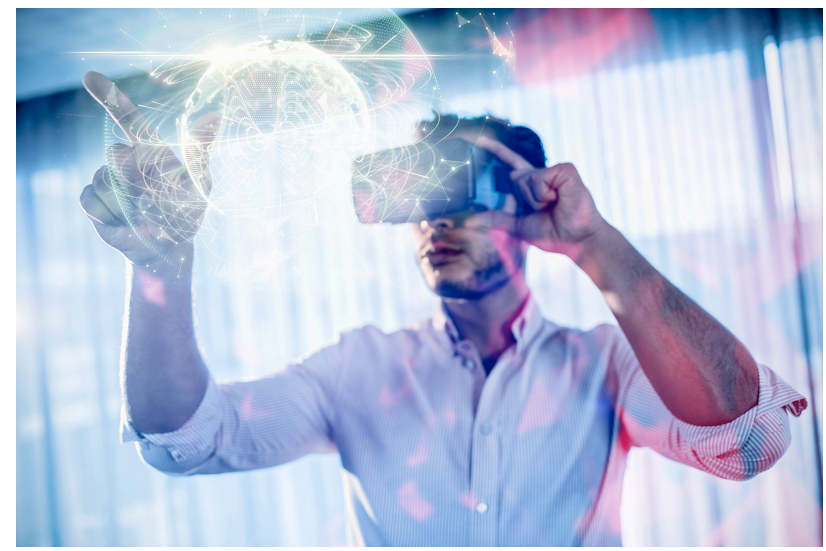

Figure 7 Acquiring gestures for VR devices

source: https://www.proximie.com/wp-content/uploads/2017/05/ARVR_compressed.jpg/

It is important to note that the utilization and researchability of second generation geoinformatics results of VR/AR technologies are not only supported by a significant increase in IT performance, but the relatively easy application of technology can also lead to a significant increase in the number of users.

Thus, a crucial issue is to create a general and expert level training of VR/AR technologies, which results in the widespread use of technology benefits and efficiency.

In order to do this the following steps are necessary:

- developing VR/AR educational content

- teacher training that enhances competences

- educational communication

- VR/AR based research sites examining geographic conditions

- establishing VR/AR based vocational training

- developing VR/AR based methodological recommendations

- etc.

\section{SUMMARY}

Geography has gone through major transformation due to the appearance of geoinformatics, which provides numerous new measuring, design and research tools for professionals (e.g.: the development of information technology and space research).

There are many points to be cleared while mapping the different geographic features and the related open issues of tenure, for which modern geoinformatics, abound with new, innovative tools, can provide simple solutions.

The emergence of VR/AR technologies can bring about the third generation step in geoinformatics, whose educational background currently raises a number of questions. Who should teach the acquisition of VR/AR competences? What should be taught? How should it be taught? Structural transformation, content development and the development of pedagogical and methodological materials are needed on the one hand, as well as the further education of professionals.

\section{REFERENCES}

[1] Cris Bevan, "Land Law", Oxford, My 15. 2018.

[2] Berke, J. - Hegedüs, GY. CS. - Kelemen, D. - Szabó, J. (2000): Digitális képfeldolgozás és alkalmazásai, (v3.0, CD melléklettel), Keszthelyi Akadémia Alapítvány - Pictron Kft., Keszthely, Budapest, ISBN $96303 \quad 9731 \quad 5 ., \quad$ DOI: 10.13140/RG.2.2.10262.14406.

[3] George Percival, "Geoinformatics applications: where to next?" COM.Geo'10 1st International Conference and Exhibition on Computing for Geospatial Research \& Application, Article No. 3. Washington, D.C., USA, June 21-23, 2010.

[4] Gulyás, I., (2011): "Vissza a természetbe - digitális osztályterem" [Back to Nature - Digital Classroom], Journal of Applied Multimedia, VI./1. pp. 16-25., ISSN 1789-6967, www.jampaper.eu.

[5] Busznyák, J. - Berke, J. (2008): The Instruction of Visual Technologies, Journal of Applied Multimedia, III/1., pp. 1-6., 2008, ISSN 1789-6967, www.jampaper.eu.

[6] Website https://spectrum.ieee.org/robotics/drones/agriculturedrones-are-finally-cleared-for-takeoff.

[7] Website Earth-i: http://geoinformatics.com/earth-i-releases-itsfirst-full-colour-video-of-earth-taken-from-space/, April 232018.

[8] Csákvári, E. - Gyulai, F. - Baktay, B. - Berke, J. (2017): The role of environmental research in education based on digital image and metadata. Journal of Applied Multimedia, XII./1. pp. 1-5., ISSN 1789-6967, www.jampaper.eu., DOI: 10.26648/JAM.2017.1.001.

[9] Major, K. - Enyedi, A. - Takács, É, - Báldoghi, T. - KozmaBognár, V. - Berke, J. (2017): Informatika mérnöki tudományos kutatói munka alkalmazása az oktatásban, XXIII. Multimedia in Education Conferences, Babes-Bolyai Tudományegyetem, Kolozsvár, Románia, 2017. június 9-10., pp. 22-30., ISBN: 978606-37-0183-2., DOI: 10.26801/MMO.2017.1.023.

[10] Major, K. - Kozma-Bognár, V. - Enyedi, A. - Váradi, Á. - Berke, J. 2016. Távirányítású drónok kutatási célú vizuális adatainak alkalmazása az oktatásban. XXII. "Multimédia az Oktatásban" nemzetközi konferencia, Keszthely; 03/06/2016, pp. 22-27., ISBN 978-615-80204-3-5, DOI: 10.13140/RG.2.1.1361.1122. 